\title{
Problems of Studying Regional Toponymicon in Linguistic Ecology Aspect
}

\author{
Dmitry Ilyin*, and Elena Sidorova \\ Volgograd State University, Department of Russian Philology, Volgograd, Russia
}

\begin{abstract}
This article studies linguistic ecology parameters for describing a regional toponymic system, which are related to intra- and extralinguistic factors including morphological derivation adaptation, local aspects and specifics of residents' life. The notion of name uniqueness within a region is introduced. Attention is paid to linguistically toxic names of inhabited localities: multicomponent names and names contradictory to the current social situation. The authors conclude that it is essential to find a balance between the language system and the language practice and the primary task of studying regional toponymicon in linguistic ecology aspect is to find means and methods protecting geographical names from the negative influence of both language environment and irresponsible actions of language speakers nominating a geographical object.
\end{abstract}

\section{Introduction}

Language development is caused by multiple intra- and extralinguistic factors. The current condition of the Russian language concerns researchers, who reflect on the decline of general language culture and loss of certain previously existing elements but are satisfied to see the evolution of language as a living and dynamic system. This ambiguous perception of language situation unites scientists of a new branch of linguistics, which name varies depending on etymology and meaning: linguistic ecology, language ecology, ecolinguistics. Terminology discussions, which are based on accumulation of empirical and practical knowledge [see: 6] and an interdisciplinary scientific approach focusing on preservation of language ethnical identity and, consequently, moral health and national safety [1, p. 28], enable us to endorse the term linguistic ecology, which has been interpreted by A. Skovorodnikov as an interdisciplinary study based on linguistics and ecology (bioecology and social ecology) and aimed at analysing language condition and its environment; positive and negative factors influencing language, social linguistic consciousness and language culture; ways to protect the language from negative impacts including internal and external borrowings unmotivated by social and cultural demands, speech vulgarization, lexical and phraseological erosion (degradation), as well as finding ways to enrich the language and promote conditions for its optimal development [12, p. 113].

\section{Methods and research}

Taking into account that one of the main objectives of linguistic ecology is studying language condition as a complex system influenced by its habitat and functioning quality and linguistic consciousness of its speakers $[10$, p. 21-22), we must emphasize that linguistic ecology views the language and the text as language product from the viewpoint of correlation of their impact on individual speakers and the society in general, analyzes the role of language in describing ecological situations and finds means to liquidate negative consequences, studies how ecological issues have been addressed in linguistics, applying linguistic terminology and methods for describing external extralinguistic reality. Thus, we may point out the transformation of linguistics from a primarily theoretical and descriptive science to a more practical one focused on finding direct solutions for problems related to the unreasonable reduction of linguistic diversity.

The aspects of linguistic ecology studies have been supplemented with new approaches, ones of which involves applying linguistic ecology approach for analyzing regional toponymicon understood as the total amount of lexemes used for naming geographical objects on a territory and, while reflecting regional specifics, possessing a unique semantic and meaningful potential implemented thought their functioning [2, p. 64].

For addressing the task to distinguish specifics of linguistics ecology condition of regional toponymicon we consider it necessary to define the ecological attributes. Describing speech and textual aspects as human activity facts, S. Ionova identifies such complicating factors as different types and effects of environmental impact on people, secondariness of informational environment allowing certain deviations to the natural material environment of human life, structural heterogeneity of informational impact objects, indirectness of informational environment impact [see:

* Corresponding author: dilyin@volsu.ru 
3]. G. Kopnina names the following ecological condition components of the language: its functioning areas; internal stratification; codification; verbalization of morale- and ethics-related concepts; negatively affecting factors, etc. [4, p. 82]. The explication of these parameters to a studied phenomenon enables us to conclude that formation and functioning of regional toponymicon are influenced not only by intralinguistic ecology-related criteria of local geographical names but also extralinguistic ones including natural geographical specifics, socioeconomic, cultural and historical regional development. Defining the scale of ecological attributes as the base for a specific language material analysis is an important linguistic task.

Volgograd Oblast is a large subject of the Russian Federation, with a population of over 2.5 million people. According to the 2016 Register of administrativeterritorial units and inhabited localities of Volgograd Oblast, the region has 475 municipal formations including 6 urban districts, 32 municipal districts, 29 cities and 408 village settlements. The obvious conclusion is that such a large set of geographical names comprising regional toponymicon has certain linguistic ecology problems. The most significant of them are as follows.

We consider it important to maintain the correlation between language system requirement and names of geographical objects. In this case, the most important factor is morphological derivation adaptation of propriatives understood as an adaptation of wordforming elements of the Russian language to existing topoformants, which promotes the similarly of their functional capacities. For instance, if we accept the version about Tatar origin of Tsaritsyn onym, according to which it derives from Sara-chin - "yellow isle", Sarasu - "yellow water" [7, p. 191], we must note that by the $19^{\text {th }}$ century this name had been assimilated completely and in the pre-Soviet period it was interpreted as a derivative of Tsaritsa hydronim and was not perceived as a borrowed word correlated to an omonymic common noun. Its morphemic structure became reinterpreted: the word, which is etymologically made out of two foreign roots, became one of the simple oikonyms containing productive topoformant $-i n-/-y n-$. Thus, in this case, the system adapted a toponymic unit to morphological derivation parameters.

The nominational potential of regional toponymicon is significantly influenced by local specifics and ethnical traits of residents. E.g., bugor Siniy (Blue Hill) got its name because in spring it is covered with small bluecoloured grass [11, p. 113]. The ethnic aspect determining proper nouns can be traced in names of inhabited localities. Volgograd Oblast has territories populated by the Cossacks, and this obviously resulted in the formation and functioning of names with an onym derived from the noun kazak (Cossack) meaning a representative of a military social strata, born in former borderline regions (Don, Kuban, Terek, Orenburg Cossacks), who was obliged to serve in special military troops using his inventory, weapons and horse in exchange for landowning privileges: Kazachiy khutor, Stepano-Razinskaya stanitsa, Stepana Razina settlement.
Ethnic specifics influence other names. E.g. Yendovsky khutor got its name from the word yendova meaning a wide bowl with a nose, which has been used by the locals, and Gonchary (Potters) village name is related to pottery production. Among names of waterbodies, the ethnocultural dependency of the hydronym may be determined by dialect definitions taken from the common noun lexis. In particular, Lake Kuzhnoye was named after kuga, a name the locals used for a certain swamp plant, the Sokarka River was named after sokar, the dialect name of a poplar [5, p. 39]. The group of toponyms with the semantics of landscape formations reflects Cossack traditions and habits: e.g. Pyany kurgan (Drunken Hill) got its name because next to it the Cossacks, newly recruited to the army, drank their last cup before leaving [11, p. 113].

Within the framework of studying regional toponymicon applying the linguistic ecology approach, we propose implementing the notion of name uniqueness within a region, which is defined as a contradiction between alleged uniqueness of regional toponymic space and commonality of toponym caused by a shared cognitive basis related to historical and cultural traditions, experience and beliefs of a nation $[9$, p. 158159]. The necessity for adopting this notion is reasoned by the fact that oikonyms, like all onyms, are meant to distinguish a singular unit within a group of similar ones (inhabited localities) by giving it an identifying name. Names, which fully meet this requirement, include many Volgograd Oblast oikonyms, including Katrichev settlement, Lopukhovka village, Arzhanovskaya stanitsa, Akishin khutor, etc. Meanwhile, shared language, culture and history of a nation living on a certain territory leads to toponymic commonality. The cause of such commonality is represented in proper nouns by the appearance of identical settlement names, which hardly promotes regional toponymical uniqueness. Volgograd Oblast has two khutors named Grachi (in Gorodishchensky and Novonikolayevsky Districts), Makarovsky (in Uryupinsky and Chernyshkovsky Districts), Ozerki (in Ilovlinsky and Kikvidzensky Districts), three Rassvet settlements (in Ilovlinsky, Kotelnikovsky and Leninsky Districts), six Olkhovsky khutors (in Kumylzhensky, Nekhayevsky and two localities with this name in both (!) Alexeyevsky and Uryupinsky Districts). Taking into account the fact that toponyms are determined to identify specific objects among similar ones, it is hard to disagree with A. Bernatskaya that the name is inseparably connected to the object and must correspond to it [1, p. 17]. However, oikonyms Zelyony (Green) and Krasny (Red) can hardly perform an identifying function even in the toponymic space of Volgograd Oblast, because this region has three settlements and two khutors named Krasny and two settlements and two khutors named Zelyony, while in Russia there are 35 Zelyony and 88 Krasny inhabited localities.

Avoidance of such absolute similarity was probably one of the reasons for appearance of "numerical names", like Beyozovka 1-ya khutor, Beyozovka 2-ya khutor in Novoanninsky District; Dyakonovsky 1-y khutor, Dyakonovsky 2-y khutor in Uryupinsky District; Zhutovo 
1-ye village, Zhutovo 2-ye village in Okyabrsky District; Knyazhensky 1-y khutor, Knyazhensky 2-y khutor in Mikhaylovsky District; Chiganaki 1-ye khutor, Chiganaki 2-ye khutor, Chiganaki 3-ye khutor in Kumylzhensky District, while Chiganaki khutor is located in Kotelnikovsky District; Yarskoy 1-y khutor and Yarskoy 2-y khutor in Kumylzhensky District, while Yarskoy khutor is located in Chernyshkovsky Districts. We believe such numerical names do not promote toponymic space ecology for several reasons: they are hard to pronounce and have different written forms (cf. Pervaya (First) Beryzovka khutor, Ilmensky 2-y khutor, Zhutovo 2-ye village) and their numeration is confusing due to its imprecision (e.g. Leninsky District has Leskhoz 5-y settlement, while this district and other regional districts have no more Leskhoz localities).

In many cases, for avoiding complete coincidence, inhabited localities names include an additional differentiating attribute, which characterizes the oikonym by its geographical position, area or the time of its foundation. Compare: Verkhnesolonovsky (Upper Solonovsky) khutor - Nizhnesolonovsky (Lower Solonovsky) khutor, Bolshoy (Big) Dubovsky khutor Maliy (Small) Dubovsky khutor, Novy (New) Kondal village - Stary (Old) Kondal village, Novogrigoyevskaya stanistsa - Starogrigoryevskaya stanitsa.

The most demanded way to differentiate onyms is to use names with the same root but varying affixal morphemes: cf. Avilov khutor -Avilovo village Avilovsky settlement; Kamyshi khutor - Kamyshin city Kamyshinsky khutor - Kamyshovka khutor.

Basing on the analysis we can define at least four levels of name uniqueness: 1) maximal level characterizes unique oikonyms (Katrcihev, Lopukhovka): 2) high uniqueness level contains morphologically related names with the same root (Zaakharov, Zakharovka, Zakharovsky); 3) medium level includes complex or composite oikonyms with the same main component, which can function as a standalone name (Novotsaritsynsky, Srednetsaritsinsky; Verkhnyaya Lipovka, Nizhnaya Lipovka, Lipovka): 4) low uniqueness level includes identical oikonyms (Volgograd Oblast has several inhabited localities named Aleksandrovka, Gromki, Zakhopersky, Kamenka, Kotovsky, Makarovsky, Rassvet and others).

The Register of administrative-territorial units and inhabited localities of Volgograd Oblast contains 1494 oikonyms, 115 of which nominate 283 localities. In other words, almost $20 \%$ of regional oikonyms has low uniqueness level. The most frequent toponym is Popov8 khutors have this name, 6 khutors share the name Olkhovsky, 5 settlements are named Aleksandrovka and Stepnoy, 4 settlements are named Beryozovka, Zhuravka, Zelyony, Krasnoyarsky, Pervomaysky, Peschanka.

Another issue troubling the toponymic ecology is related to making a difficult choice whether to right the oikonym as one word or separate its elements with a hyphen. Although the new edition of The Rules of Russian Orthography and Punctuation adopted in 2006 contains, in comparison to a 1956 version, a special part on writing toponyms, we believe in most cases these rules lack the necessary imperativeness. Substitution of strict rules with description, according to which that toponyms with certain structural elements are written differently, some are traditionally written as one word (in maps and documents) while others are hyphenated [8, p. 115], is driven by desire of linguists to legitimize existing variants; however, this fails to solve severe orthographical difficulties language speakers have to face when similar names of localities have different written forms, cf. Novo-Aleksandrovka village (Ryazan Oblast) - Novoaleksandrovka village (Omsk Oblast), Staro-Russkoye village (Tver Oblast) - Starorusskoye village (Sakhalin Oblast) Belo-Pashino village (Kirov Oblast) - Belopashino village (Arkhangelsk Oblast), Novo-Ivanovskoye village (Tver Oblast) NovoIvanovskoye village (Moscow Oblast) Novoivanovskoye village (Leningrad Oblast), VerkhneNikolskoye village (Ryazan Oblast) - Verkhnenikolskoye village (Voronezh Oblast), Novo-Mikhaylovka village (Tomsk Oblast) - Novomikhaylovka village (Orel Oblast).

Inhabited localities are characterized from the viewpoint of their residents as well as enterprises and organizations operating on their territory, so their onyms must be capable of making derivatives. The linguistic ecology approach demonstrates the necessity for a system of toponymic derivatives. In particular, difficulties arise during formation of katoikonyms collective names for residents of a particular territory from such names as Boykiye Dvoriki khutor, Rekonstruktsiya settlement, Trudolyubiye village, TrudRassvet khutor, making these toponyms unable to be positivity estimated from a linguistic ecology standpoint.

\section{Conclusion}

Finally, the following toponyms should be considered linguistically toxic: multicomponent names, due to pronunciation (and/or spelling) difficulties: Dom Otdykha 40 Let Oktyabrya settlement, Oblastnoy Selkhokhozyastvennoy Opytnoy Stantsii settlement, Fermy Nomer 3 Plemzavoda "Parizhskaya Kommuna" settlement, and geographical names contradictory to current social situation and tendencies, like Krasny Pakhar (Red Plowman) settlement, Krasny Meliorator (Red Ameliorator), Krasny Buksir (Red Tow) settlement, Kommunar (Communard) settlement, Mayak Oktyabrya (October Beacon) settlement, Politotdelskoye (Political Division) village, Vtoraya Pyatiletka (Second Five-year Plan) settlement, Leninets (Lenin Follower) settlement.

Thus, the relevant task of forming the linguistic ecology image of regional toponymicon is to find means and methods protecting geographical names from the negative influence of both language environment and irresponsible actions of language speakers nominating a geographical object and to find a balance between the language system and the speech practice.

This research has been performed with financial support from the Russian Foundation for Basic Research, scientific project 18-12-0064: Linguistic Ecology Image of Regional Toponymicon: Problems, Controversies and Solutions. 


\section{References}

1. A.A. Bernatskaya, Ecology of language and communicative practice 2, 15-31 (2014)

2. D.Y. Ilyin, Toponymic lexis in regional newspaper articles of late $19^{\text {th }}$-early $21^{\text {st }}$ centuries: dynamic processes (Volgograd State University Publishing House, Volgograd, 2012)

3. S.V. Ionova, Ecology attributes and the problem of their distinction in linguistic ecology. Emotive linguistic ecology in modern communicative space (Peremena, Volgograd, 2013)

4. G.A. Kopnina, Ecology of language and communicative practice 2, 78-89 (2014)

5. R.I. Kudryashova, Traditional word. Subdialects of Volgograd Oblast in the past and the present (Peremena, Volgograd, 1997)

6. N.A. Kurashkina, Ecology of language and communicative practice 2, 143-156 (2015)

7. E.M. Pospelov, Russian geographical names: toponymic dictionary (AST: Astrel, Moscow, 2008)

8. The rules of Russian orthography and punctuation. Complete academic reference (AST-PRESS KNIGA, Moscow, 2009)

9. E.G. Sidorova, Lingua-ecological problems of toponimic space of a region, Ecology of language and communicative practice 2, 157-166 (2015)

10. A.P. Skovorodnikov, The ecology of the Russian language (Siberian Federal University, Krasnoyarsk, 2016)

11. E.A. Chemyakin, Cossack family names and... (etymology, hydrotoponymics, local history) (Print, Volgograd, 2005)

12. The ecology of the Russian language. Dictionary of linguistic ecology terms (FLINTA: Nauka, Moscow, 2017) 